\title{
Analysis of the influence of physical and mental workload on worker productivity in bakery SME
}

\author{
Ellena Nurmasari*, Mirwan Ushada, and Endy Suwondo \\ Department of Agroindustrial Technology, Faculty of Agriculture Technology, \\ Universitas Gadjah Mada, Jl. Flora No.1, Bulaksumur, Yogyakarta, Indonesia \\ *e-mail: ellena.nurmasari@mail.ugm.ac.id
}

\begin{abstract}
The worker is one of the important factors in Small Medium-sized Enterprise (SME) because of manual production. Workload and daily production target influence worker productivity. The research objectives are: 1) To measure worker physical and mental workload in Bakery SMEs; 2) To analyze the relationship between physical, mental workload and productivity. The case study of research is in SME an anonymous bakery SME in Sleman. Physical workload indicator was based on heart rate. Heart rate was measured using wrist pulsemeter. Cardiovascular load percentage was calculated using measured heart rate work and leisure time. Mental workload indicator was measured NASA-TLX questionnaire. It had six indicators as mental, physical, temporal demand, performance, effort, and frustration level. Productivity was identified by the dough output. The relationship between physical, mental workload and productivity were analyzed using polynomial quadratic regression. The result concluded the worker productivity in bakery SME was influenced by physical and mental workload as much as $80.8 \%$ and $19.2 \%$ influenced by other factors. The result of $80.8 \%$ was significant compared to the other one in SMEs. This result provided the linear model opportunity to be used easily instead of non-linear to define the worker and production system interaction in SMEs.
\end{abstract}

\section{Keywords}

Heart rate, Polynomial quadratic regression, Questionnaire of NASATLX

Citation: Nurmasari, E., Ushada, M., \& Suwondo, E. (2018). Analysis of the influence of physical and mental workload on worker productivity in bakery SME. In T. R. Nuringtyas, A. C. Sukartiko, \& A. Isnansetyo (Eds.), UGM Digital Press Life Sciences: Vol. 1. Proceeding of the 2nd International Conference on Tropical Agriculture, (pp. 21-29).

Published: October, 2018

\section{Introduction}

Since the last few years, SME's sector indicates the significant increase development. Small Medium-sized Enterprise (SME) in Sleman, Yogyakarta is always growing up to $10 \%$ every year. Until the end of December 2015, total number of SMEs is as much as 137.267. The empowerment of SME in the mid of globalization and high competition make SME must be able to face global challenges, such as improve product and service innovation, human resources and technology development, and expansion of marketing area [11]. The productivity of SME system should be increased. Productivity is defined as the 
relationship between input and output of a production system. Most of the SME has manual production system, so worker is one of important factor to finish all targets. In addition to be the most important asset to the company, worker is also one of the largest cost components in the SME. Achievement of performance management is very dependent on work productivity, in this case is the productivity of worker [12]. Workload is an effort that must be issued by a worker to do their job. There aremany external factors that affect the workload. One example is the workload that comes from physical factors such as workstations, space, work, tools and means of work, working conditions, job attitudes, and tasks. For psychological factor as the complexity of the work, the difficulty level, the responsibilities of the job, and the organization of work, such as the length of work, rest periods, work shift, night shift, wage system, organizational structure, duties. The workload is closely related to the workforce, so it also affects the productivity of work; the level of its influence varies for each worker [2].

\section{Methods}

The study was conducted in anonymous Bakery SME Sleman, Special Region of Yogyakarta. The study used primary data as the number of bread produced, the results of heart rate before and after work, the results of NASA-TLX questionnaire, working environment, temperature conditions, and work time. Secondary data was obtained from journals, books, and related literature research [7]. Data-related with the work environment is temperature data. A worker could be affected by the pressure of the heat and show symptoms that can be measured as a pulse rate. The temperature of the working environment could be a problem for heart rate worker. Productivity was identified by the bread dough production divided by hours of work. The measurement indicator of the workload of physical worker is seen using the heart rate of worker. There was assumption that increasing the pulse of the workforce increases the workload indicated the type of worker. Physical workload is calculated by the results of observation towards the workforce using a wrist sensor pulse meter before work and after work. In addition, the interview related with the workforce age is also done. Assessment of mental workload used the NASA-TLX with questionnaire to worker-related mental workload. In this section, respondents were asked to assess the questionnaire weight and give rating against the six indicators of mental load. The given rating is subjective depending on the mental workload felt by the respondents. The NASA-TLX questionnaire was measured in calculating the value of products, WWL (weight workload), and finding the average WWL and NASATLX score interpretation. The test of normality is used to identify data errors. This could be pursued with the Kolmogorov Smirnov test. This test is based on a comparison of cumulative distribution functions with the cumulative distribution functions of the hypothesis. Data is normal when the value of Asymp. sig (2-tailed), greater than the limit of significance (0.05) [6]. To see the level of influence of the physical and mental workload to productivity is using regression analysis. The regression model used is quadratic polynomial regression. The model was based on an analysis of the patterns of data. Regression was calculated using SPSS statistics software 21. The dependent variables used are related to the calculation result of productivity each day for doing research, while the independent variable is the result of observation of the physical and mental load. Classical assumptions of the test is a test performed to analyze the basic assumptions which must be fulfilled in the use of regression. This classic assumption test aims to produce unusual linear estimator of the best regression models obtained from the smallest squares method.

\section{Results and Discussions}

\subsection{Identification of Forming the Dough Work Station}

Workstations that form the dough have 10 workers. After the dough was already in appropriate quality standards and ready to be shaped according to the type and flavor, the worker should make the dough in a targeted quantity. Workers in the workstation form the dough in a big target because of 600014000 bread per day. With a large number of targets, forming the dough has a limited time because after 
forming the dough, the next step is fermentation. Fermentation required time to wait until the dough expands.

Forming the dough is the longest production time in SMEs. The more efficient the workstation,the better product will make. Forming the dough has some elements of work that can be seen in Fig. 1.

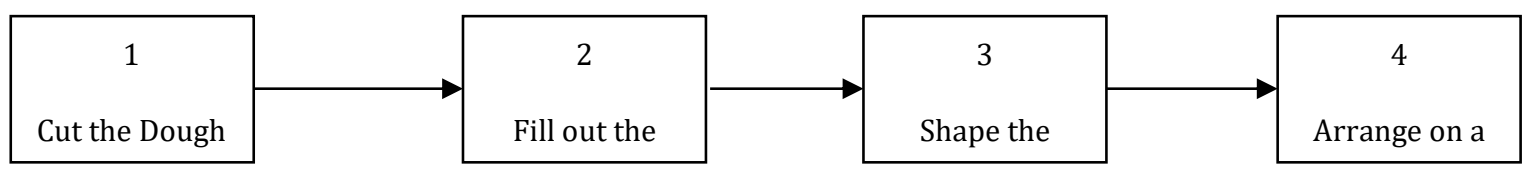

Fig. 1 Forming the Dough Work Elements

\subsection{Identification of the Work Environment}

Work environment exists around the worker and an affect them in daily production. Temperature is an important thing that affects a person's workload because temperature affects the person's heart rate [7]. Temperature data was measured using the tool for Temperature and Humidity Data Logger. The measurement was conducted before and after work. The obtained results of the temperature measurement in the workstation are $30.03 \pm 2.55{ }^{\circ} \mathrm{C}$. According to the Minister of Health decree number $1405 /$ Menkes/SK/XI/2002 for a room temperature is $18^{\circ} \mathrm{C}$ and the highest limit is $30^{\circ} \mathrm{C}$, so it can be said that the conditions of the working environment in the workstationis too hot and can cause fatigue.

\subsection{Physical Workload}

Determination of the physical workload by measuring the amount of heart rate and body temperature to the obtained energy levels, workload, energy consumption and percentage of the cardiovascularload foreach worker on the workstations. The results of the measurement of workers' heart rate before the work can serve as a heart rate of a worker at rest or not in working condition. In addition, it takes the workers' age for the data. CVL (Cardiovascular Load) can be calculated using the difference percentage of the sum of work heart rate and rest heart rate within the maximum heart rate and resting heart rate, and then multiplied by 100 .

Table 1 The Result of Cardiovascular Load

\begin{tabular}{|l|l|l|l|l|}
\hline Worker & $\begin{array}{l}\text { Age } \\
\text { (Year) }\end{array}$ & $\begin{array}{l}\text { Average resting } \\
\text { heart rate/minutes }\end{array}$ & $\begin{array}{l}\text { Average Working Heart } \\
\text { Rate/minutes }\end{array}$ & \% CVL \\
\hline 1 & 26 & 85.67 & 107.67 & 25.68 \\
\hline 2 & 18 & 81.33 & 112.67 & 38.52 \\
\hline 3 & 18 & 80 & 115.67 & 44.58 \\
\hline 4 & 23 & 81.67 & 116.67 & 42.86 \\
\hline 5 & 33 & 78.67 & 110 & 39.83 \\
\hline 6 & 35 & 77.67 & 118 & 51.93 \\
\hline 7 & 20 & 76 & 108 & 42.11 \\
\hline 8 & 42 & 82 & 115.33 & 40.65 \\
\hline 9 & 40 & 84.33 & 114.33 & 35.57 \\
\hline 10 & 31 & 88 & 113.33 & 28.79 \\
\hline
\end{tabular}


From Table 1, it can be identified that out of ten workers, there are two workers that lower than $30 \%$, so that is not the case of fatigue. For the second classification with $30 \%$ to $60 \%$ of CVL there are 8 workers who need improvements. Both the classification above can be explained that some workers feel exhausted and need improvements to balance the workload [9].

\subsection{Mental Workload}

Every mental activity will always involve an element of perception, interpretation and the mental processes of information received by the sensory organs to take a decision or the process of recalling the stored information. There are six aspects in the questionnaire of the NASA-TLX. Qualitative assessment of workforce-related has six aspects. Aspects that are assessed in the questionnaire of the NASA-TLX, namely:

\subsubsection{Mental Demand (MD)}

This concerns aspects of mental activity conducted within the workstations of the dough formation. The mental aspects can be the activity of thinking, observing, and remembering in the workstation. Moreover, it can also be seen from the level of difficulty of the work.

\subsubsection{Physical Demand (PD)}

This concerns aspects of physical activities that are carried out within the workstations of the dough formation. How high or low the needs or fatigue are felt in doing the work.

\subsubsection{Temporal Demand (TD)}

This aspect is related of time that takes to complete a job at workstation of the dough formation.

\subsubsection{Performance $(P)$}

This aspect concerns the level of workers achievement at a time when they finish make dough.

\subsubsection{Frustration Level (FR)}

This aspect concerns the level of stress, feelings of insecurity, feeling of despair felt by workers at workstations of the dough formation, compared with feeling of being safe and comfortable.

\subsubsection{Effort (EF)}

This aspect concerns the level of effort required and perceived in completing the work to the target workstation of the dough formation. 
Table 2 The Result of Mental Workload

\begin{tabular}{|l|c|c|}
\hline Worker & WWL & The Value of Mental Workload \\
\hline 1 & 890 & 59.33 \\
\hline 2 & 970 & 64.67 \\
\hline 3 & 985 & 65.67 \\
\hline 4 & 1140 & 76.00 \\
\hline 5 & 1135 & 75.67 \\
\hline 6 & 1020 & 68.00 \\
\hline 7 & 1045 & 69.67 \\
\hline 8 & 1045 & 69.67 \\
\hline 9 & 1135 & 75.67 \\
\hline 10 & 1150 & 76.67 \\
\hline
\end{tabular}

The average mental workload was 70.10 and categorized into the medium load. The biggest perceived mental workload is the $10^{\text {th }}$ worker since he gives a high score on each assessment. The lowest mental workload felt by the worker is firstly observed, because workers had high spirits.

The spirit of work experienced by every worker tends to be high; although a lot of work demands and difficulties, the working environment between workers are very well. A good relationship between workers made good organization work [10]. The good atmosphere is caused by the work atmosphere and friendly co-worker in their daily job. The level of fatigue of the workers influences the value of the perceived mental workload. The worker tiredness changes the atmosphere and can influence other workers.

Sources of stress in the work environment can cause psychological stress, such as bad physical work, heavy work, loose tempo, simple work, role conflict, bad relationship with superior and the boring environment [1].

\subsection{Worker's Productivity}

Productivity measurement was carried out to see the level of productive workers or ability to complete the production target [5]. Productivity measurement was conducted by measuring the workers' ability to do the job at the workstation of the formation of the dough. The observation is done by calculating the amount of dough that can be produced by a worker at the targeted time.

The workers' productivity level in forming the dough does not have a great significance because the ability of the worker is balanced. The difference is in the number of inputs of the number of requests and the number of different bread. The production process at the workstation of the dough formation was pursued manually. 
Table 3 The Result of Productivity Level

\begin{tabular}{|l|c|}
\hline Worker & Productivity Level (dough every hour) \\
\hline 1 & 158.06 \\
\hline 2 & 315.38 \\
\hline 3 & 302.08 \\
\hline 4 & 295.52 \\
\hline 5 & 320.00 \\
\hline 6 & 340.91 \\
\hline 7 & 357.35 \\
\hline 8 & 296.58 \\
\hline 9 & 276.92 \\
\hline 10 & 255.10 \\
\hline
\end{tabular}

The higher productivity of worker on workstations of the dough formation will affect the subsequent processes. The higher worker productivity, the work will finish faster. In addition, the worker at workstation of the dough formation must have skill due to the variation in rules.

The increase productivity could be achieved by holding down the last detail of costs included utilizing human resources and increase the output. In other words, productivity is a reflection of the level of efficiency and effectiveness of work in total [3]. Productivity management must be pursued to achieve the best productivity of all aspects, including worker. Productivity management can be done by identifying the factors that can affect the level of productivity itself. The workload is one of the things that can be identified in the level of influence.

\subsection{Kolmogorov Smirnov Normality Test}

The basic concept of Kolmogorov Smirnov test for normality is to compare the distribution of raw data with a normal distribution [6]. Result of the Kolmogorov-Smirnov is a value of Asymp. sig (2-tailed) 0.417. The data have a normal distribution if the value of Asymp. sig. (2-tailed) is more than 0.05. If data processing shows the value less than 0.05 , data distribution is not normal. Since 0.05 is bigger than 0.417 , it can be concluded that the Gaussian data.

\subsection{Identification of Data Patterns}

Results of curve estimation variable are bound between productivity and physical workload-independent variable illustrating that the highest $\mathrm{R}$ Square value in quadratic data pattern as much as 0.808 , whereas for linear data pattern only gets 0.685 for R Square. For other patterns, nothing exceeds the R Square value on quadratic. The value sig quadratic function is 0.03 and it is smaller than 0.05 . So, this variable has a quadratic polynomial data pattern, because two assumptions is approved.

Data patterns between mental workload with productivity is a quadratic function with R square 0.850 and sig. 0.001 , because linear data pattern only gets 0.114 . So that variables have quadratic polynomial data pattern too.

\subsection{Correlation Analysis}

The correlation analysis is a method that is used to see relationships or correlations between three or more variables. Two or more variables are said to be correlated when a change in one variable is followed by changes in other variables, either unidirectional or not. 
The linear relationship will be more powerful or have a high degree of relationship between two straight variables lines or more. Each range is between 0 and 1 . A positive correlation value shows that the correlation goes in the opposite direction; if the value of the correlation coefficient is negative, the correlation does not run in the same direction. If the correlation coefficient is +1 , the relationship is referred as a perfect correlation or a linear relationship with a negative slope. If the coefficient correlation is 1 , then the relationship found referred as perfect correlation or linear relationship with a negative slope. The result of the correlation between productivity with physical load is 0.827 , whereas the correlation between productivity with the mental workload is 0.338 . Correlation between physical loads with variable productivity has a very strong value whereas productivity with mental workload has weak value. The corresponding relationship between two variables is independent in the form of physical and mental workload that has a value of 0.083 . The relationship could be categorized as weak.

\subsection{Influence Level of Physical and Mental Workload with Worker Productivity}

The level of influence between variable against independent was indicated from the beta values on the component coefficients. Based on calculations, the level of influence of physical workload on productivity is 1.525. The influences level of quadratic is -1.137 and the total level of influence of physical load of 0.388 or $38.8 \%$. The influence of mental workload to the productivity of 13.477 whereas the influences level of quadratic is -13.237 and total influence mental workload is 0.24 or $24 \%$.

Table 4 Coefficients Polynomial Quadratic Regression

\begin{tabular}{|c|c|c|c|c|c|}
\hline \multicolumn{6}{|c|}{ Coefficients $^{\mathbf{a}}$} \\
\hline \multirow{2}{*}{\multicolumn{2}{|c|}{ Model }} & \multicolumn{2}{|c|}{ Unstandardized Coefficients } & \multirow{3}{*}{$\begin{array}{l}\text { Standardized Coefficients } \\
\text { Beta }\end{array}$} & \multirow{3}{*}{$\begin{array}{l}\mathrm{T} \\
-0.892\end{array}$} \\
\hline & & \multirow{2}{*}{$\begin{array}{l}\text { B } \\
-116.753\end{array}$} & \multirow{2}{*}{$\begin{array}{l}\text { Std. Error } \\
130.901\end{array}$} & & \\
\hline \multirow[b]{3}{*}{1} & (Constant) & & & & \\
\hline & Physical workload & 5.871 & 1.362 & 0.805 & 4.309 \\
\hline & Mental workload & 2.558 & 1.765 & 0.271 & 1.449 \\
\hline & (Constant) & -419.402 & 2297.217 & & -1.924 \\
\hline & Physical workload & 11.121 & 12.183 & 1.525 & 0.913 \\
\hline & Mental workload & 127.31 & 71.117 & 13.477 & 1.79 \\
\hline & Physical workload Sq & -0.108 & 0.147 & -1.137 & -0.737 \\
\hline & Mental workload Sq & -0.905 & 0.511 & -13.237 & -1.77 \\
\hline
\end{tabular}

a. Dependent Variable: Productivity

The cause of the physical workload influences the productivity since every work has a maximum capacity that determines the level of worker fatigue [8]. Besides, the elements of age and gender also affect the perceived load level for the physical. Position and way of working can also increase fatigue at work. The physical workload can be managed to keep the productivity of the worker, such as reducing the temperature at working area or minding the position and way of working of the worker. The standingsitting position has advantages in bio-mechanical that pressures the spine and waist $30 \%$ lower compared with the sitting position or stand continuously. It certainly can be used as consideration in the application of ergonomics interventions; the position of the worker is sitting or standing can provide benefits for most of the worker. In addition, this improvement in work position can also reduce the overload work that will affect the mental worker. 
The result of the regression equations was second order polynomial with productivity and workload variables as follows:

$$
Y=-419.402+11.121 X 1-0.108 X 12+127.31 X 2-0.905 X 22
$$

The equation above defines productivity is $Y$, the Physical workload is $X_{1}$ and the mental workload is $X_{2}$. The experienced worker's workload can lower work productivity of workers, the determination of the workload of each individual should plan to match the capacity of every worker. Work productivity of an enterprise could be achieved to the maximum if comply with the planning of individual workload before placed on the specific parts.

Table 5 Model Summary of Influence

\section{Model Summary}

\begin{tabular}{|c|c|c|c|c|c|c|c|c|c|}
\hline \multirow{2}{*}{ Model } & \multirow[t]{2}{*}{$\mathrm{R}$} & \multirow{2}{*}{ R Square } & \multirow{2}{*}{$\begin{array}{l}\text { Adjusted R } \\
\text { Square }\end{array}$} & \multirow{2}{*}{$\begin{array}{c}\text { Std. The error } \\
\text { of the } \\
\text { Estimate }\end{array}$} & \multicolumn{5}{|c|}{ Change Statistics } \\
\hline & & & & & $\begin{array}{c}\text { R Square } \\
\text { Change }\end{array}$ & F Change & df1 & $\mathrm{df} 2$ & $\begin{array}{c}\text { Sig. F } \\
\text { Change }\end{array}$ \\
\hline 1 & $.870^{\mathrm{a}}$ & .757 & .688 & 30.95716 & .757 & 10.929 & 2 & 7 & .007 \\
\hline 2 & $.945^{\mathrm{b}}$ & .893 & .808 & 24.29088 & .136 & 3.185 & 2 & 5 & .128 \\
\hline
\end{tabular}

a. Predictors: (Constant), Mental workload, Physical workload

b. Predictors: (Constant), Mental workload, Physical workload, Physical workload Sq, Mental workload Sq

c. Dependent Variable: Productivity

In Table 5, in the polynomial quadratic model, the result of $R$-value, $R$ square value, and Adjusted $R$ Square Value were $0.945,0.893$, and 0.808 , respectively. $R$ square indicated the determination of the coefficient by squaring the correlation coefficient (R). It could be described that the ability of the independent variable defined a variant dependent variable of $89.3 \%$. This study uses two independent variables, and then it used the value of Adjusted R Square because the value of Adjusted R Square can rise or fall with the addition of variables. It can be concluded that the influence of the physical workload and mental workload against the worker productivity to $80.8 \%$, influenced by other factors of $19.2 \%$. From Table 5 on rate changed the influence of linear regression analysis model with polynomial quadratic regression of 0.128 or $12.8 \%$. The polynomial quadratic model is more appropriate to analyze the influence of the physical and mental workload against the productivity of the worker.

\section{Conclusions}

The average load of a physical worker with Cardiovascular Load calculation was $39.05 \%$. The mental workload had an average of 70.10. The physical workload of a worker at workstations of the dough formation was in the needed repairs category while the mental workload of a worker in the medium category.

The level of lowest productivity was 158.06 doughs every hour. The highest level of productivity was 357.35 doughs every hour. The influence of physical workloads against worker productivity is at $38.8 \%$. The influence of mental workload against the worker productivity is at $24 \%$. The influence both of the workload and productivity could be seen from the value of the adjusted R square of $80.8 \%$. The productivity was influenced by the physical and mental workload of $80.8 \%$ and $19.2 \%$ influenced by other factors. 


\section{References}

1. Anies: Penyakit akibat kerja: Berbagai penyakit akibat kerja dan upaya penanggulangannya. [Occupational diseases: Various occupational diseases and their countermeasures]. Elex Media Komputindo, Jakarta (2015). [In Bahasa Indonesia].

2. Sweeney, A., Evans, W.: Applied production and operations management. $2^{\text {nd }}$ Edition. West Pub. Co., New York. (1987).

3. Manuaba, A.: Penerapan ergonomi untuk meningkatkan kualitas sumber daya manusia dan produktivitas. [Implementation of ergonomics to improve the quality of human resources and productivity]. In: Seminar Kesehatan dan Keselamatan Kerja (K3). IPTN Bandung (1992). [In Bahasa Indonesia]. [Online Unpublished].

4. Kementerian Kesehatan RI: Persyaratan kesehatan lingkungan kerja perkantoran dan industry [Health requirements of office work environment and industry]. Kementrian Kesehatan, Jakarta (2002). [In Bahasa Indonesia].

5. Heizer,J., Render, B., Sungkono, C.: Manajemen operasi [Operations management]. $9^{\text {th }}$ Edition. Salemba Empat, Jakarta (2009). [In Bahasa Indonesia].

6. Paryono, P.: Mengolah data statistik dengan SPSS/PC+ [Processing statistics with SPSS/PC+]. Andi Publisher, Yogyakarta (1994). [In Bahasa Indonesia].

7. Salimi. I.R.S.: Kesehatan dan keselamatan lingkungan kerja [Occupational health and safety]. Gadjah Mada University Press, Yogyakarta (2015). [In Bahasa Indonesia].

8. Ulfah, N., Nurcahyo, P.J., Dwiandhono, I.: Model kuantitatif manajemen kelelahan dan beban kerja untuk peningkatan produktivitas pekerja penggilingan padi [Quantitative model of fatigue management and workload for increasing productivity of rice millers]. Jurnal Kesehatan Masyarakat Nasional 7(10), 1-4 (2013). [In Bahasa Indonesia].

9. Wignjosoebroto, S.: Ergonomi, studi gerak, dan waktu - Teknik analisis untuk peningkatan produktivitas kerja. [Ergonomics, motion study, and time: Analysis techniques for increasing work productivity]. Guna Widya, Surabaya (2002). [In Bahasa Indonesia].

10.Zainun, B.: Administrasi dan manajemen kepegawaian pemerintah negara Indonesia. [Administration and human resources management government of Indonesia]. Gunung Agung, Jakarta. (1991). [In Bahasa Indonesia].

11.Dian.: Usaha kecil menengah. [Small and medium enterprises]. Harianjogja. (2016). [In Bahasa Indonesia]. https://harianjogja.com

12. Lantum, A.K.: Pengembangan sumber daya manusia dalam meningkatkan produktivitas. [Development of human resources in increasing productivity]. Kajian Bisnis No. 8, 52-62. STIE Widya Wiwaha, Yogyakarta. (1996). [In Bahasa Indonesia]. [Online unpublished] 